public meetings arranged by the French Association of Scientific Workers under the auspices of the Centre National de la Recherche Scientifique, which have been going on since early spring. The meetings have been divided into lectures on laboratory technique, public lectures on current scientific topics and visits to laboratories. The programme, which contains rore than a hundred entries, reveals an enthusiasm that augurs well for the resurgence of science in Paris.

\section{Physical Society: Presentation of Duddell Medal}

Aт a meeting of the Physical Society to be held at the Royal Institution at 4 p.m. on May 23 the Duddell Medal for 1944 will be presented to Dr. F. W. Aston in recognition of his invention and subsequent development of his mass spectrograph. This instrument, first designed and constructed in 1919, made use of a new and ingenious method of electromagnetic focusing and enabled Aston to establish that many elements consist of mixtures of isotopes, as foreshadowed by J. J. Thomson's work on noon. With later modifications of the instrument, Aston investigated most of the known elements and showed that all the stable isotopes, of which he discovered hundreds, had nearly integral masses, taking $\mathrm{O}$ as 16 . Aston's later work is concerned mainly with the small deviations from this whole-number rule, representing the binding energies of the isotopes in the nucleus. Using a much improved mass spectrograph, he measured masses with a precision of 1 in 20,000 and determined the binding energies in isotopes of the lighter elements with great accuracy. Finally, from the masses and the photometrically determined relative abundances of the isotopes, Aston calculated "chemical atomic weights" for comparison with, and as a check upon, the results of other methods. At the same meeting, Prof. E. N. da C. Andrade will deliver his presidential address, taking as his subject "The History and Future of the Physical Society".

\section{Belgian Delegation in Britain}

A SECOND group of Belgian professors, representing the Belgian Fondation Universitaire, is visiting Britain for a fortnight at the invitation of the British Council. For five of them it is their first visit to this country. The delegates are: Prof. Jean Brachet, Faculty of Science, Brussels ; Prof. Marcel' Homes, Faculty of Science, Brussels; Prof. Henri Koch, Faculty of Comparative Physiological Science, Louvain; M. Marius Lecompte, keeper of the Belgian Royal Museum of Natural History; Prof. Jean Louis, State Agricultural Institute, Gembloux; Prof. Victor Van Straelen, Faculty of Science, Ghent, and Brussels; Dr. Pierre Wigny (law and legal science); Prof. Jean Haesaert, Faculty of Law, Philosophy and Letters, Ghent ; Prof. Paul Rousseau, Faculty of Law, Louvain; Prof. Paul de Visscher, Faculty of Law, Louvain. Among the places the delegation will visit are the British Museum, the Imperial College, Kew Gardens and the Bureau of Micrology, University College, London, the London School of Hygiene and Tropical Medicine, the Society for Visiting Scientists, Rothamsted Experimental Station, Oxford and Cambridge.

\section{Advisory Committee on Building Research}

The Minister of Works has appointed a scientific advisory committee to advise on and to suggest lines of scientific research; to suggest where this research could best be carried out and to keep it under review ; and to advise on the practical possibilities and further development of the results of current research. The committee consists of Prof. J. D. Bernal (physics), Birkbeck College, London (chairman) ; Dr. E. F. Arm. strong, member of Building Research Board; Prof. J. F. Baker (mechanical sciences), University of Cambridge; Prof. P. M. S. Blackett (physics), University of Manchester; Prof. W. E. Curtis (physics), University of Durham; Dr. C. C. Douglas, University of Oxford, chairman, Joint Committee on Heating and Ventilation (Building Research Board and Industrial Health Research Board); Prof. C. D. Ellis (physics), King's College, London; Prof. I. M. Heil. bron (organic chemistry), Imperial College of Science and Technology, London, scientific adviser, Ministry of Production; Prof. J. M. Mackintosh (public health), University of London; Mrs. J. V. Robinson, lecturer in economies, University of Cambridge ; Sir Ernest Simon, chairman, Advisory Council, Ministry of Fuel and Power; Mr. F. E. Smith, chief superintendent, Armament Design Dept.; Prof. W. N. Thomas (engineering), University College, Cardiff ; and Prof. S. Zuckerman (anatomy), Universities of Oxford and Birmingham. Mr. I. G. Evans, director of building research ; Lord Amulree, medical officer, Ministry of Health; and Dr. R. S. F. Schilling, secretary, Industrial Health Research Board, are assessors. Sir Reginald Stradling is executive officer.

\section{Release of Requisitioned Land and Premises}

THE second report from the Select Committee on National Expenditure for the Session 1944-45 deals with the release of requisitioned land and buildings. It emphasizes the weaknesses in existing land legislation which were stressed during the debate in the House of Commons on the Requisitioned Land and War Works Bill, and shows the need for incorporating in the Bill provisions to amplify the assurances which Sir John Anderson gave to the House of Commons in that debate. An instance cited in the report of an airfield constructed on 600 acres of farm land and 260 acres of common land in the 'green belt', into which the Select Committee inquired, shows that existing legislation fails to protect common land or to provide for its reinstatement. The menace to the countryside which still persists is shown by two further examples : the Admiralty's claim to Bodmin Moor, rich in archæological interest and potentialities for research, and also an important catchment area, for use as a bombing range-since dropped-and the War Office inability to say whether the tract between the Frome River and Studland and Swanage Bays, cleared for training purposes, is to be restored to public use.

On the question of premises, the Select Committee's report indicates that the fundamental need is the same, and its principal recommendation is that a supervisory authority should be entrusted with the task of pressing for the release of requisitioned premises, bearing in mind urgent civilian needs ; and a central and independent review of the use of premises and of storage requirements should be instituted and pressed forward with all practicable speed. But while a valuable system of co-ordinating the release of requisitioned land and premises has been devised, the little use that has so far been made of it is not to be attributed entirely to departmental reserve or inaction: it is due at least in part to the absence of decisions at the centre. The report recommends that the Government should not only come to an early decision whether it is more 